\title{
BLOWBY GAS COMPOSITION IN SI ENGINES
}

\section{KAREL PÁV}

ŠKODA AUTO a.S., tř. Václava Klementa 869, Mladá Boleslav 293 60, Tel.: 326815450, Email: karel.pav@skoda-auto.cz

\section{SHRNUTÍ}

Tento příspěvek se zabývá metodikou měření složení blow-by plynů v klikové skř́ni motoru s využitím konvenčních NDIR analyzátorů výfukových plynů. Vyhodnocení je zaměřeno na určení podílu spalin, paliva a vodních par obsažených v těchto plynech. Určení podílu spalin v blow-by plynech je založeno na měření koncentrace $\mathrm{CO}_{2}$. Výsledky měření na větším počtu zážehových motorů jsou statisticky zhodnoceny s ohledem na provozní podmínky motoru. Je zde rovněž ukázán vliv různých provozních podmínek motoru a vliv různého typu použitého paliva na složení blow-by plynů zážehových motorů s vnější tvorbou směsi.

KLÍČOVÁ SLOVA: BLOW-BY PLYNY, PODÍL VÝFUKOVÝCH PLYNŮ, PODÍL VODNÍCH PAR, ZÁŽEHOVÝ MOTOR, CNG MOTOR.

\section{ABSTRACT}

The paper deals with a procedure for measuring the composition of blowby gas in the engine crank case by means of a conventional NDIR (Non-Dispersive Infra-Red) exhaust gas analyzer. This paper aims to evaluate the exhaust gas portion, as well as the fuel and water vapor fraction in the raw blowby gas. Determination of the exhaust content in the blowby gas is based on $\mathrm{CO}_{2}$ concentration measurement. The measurement results of several SI engines are statistically reviewed regarding the engine operational points. The influence of different operational conditions and used fuel type is shown on raw blowby gas composition in port injection SI engines. KEYWORDS: BLOWBY GAS, EXHAUST GAS FRACTION, WATER STEAM FRACTION, SI ENGINE, CNG ENGINE.

\section{INTRODUCTION}

The blowby flow into the crank case is caused by imperfect sealing of the combustion chamber during the engine cycle. Due to the leakage of piston rings, the working gas flows down along the piston skirt. Dynamic movement of the piston rings is a very complex issue and can be behind an unpredictable leakage. Normally, the main flow occurs in the high pressure part of the working cycle, but due to the piston ring movement or fluttering a significant flow can also be observed in the low pressure part. The blowby gas consists of fuel vapor which negatively affects the oil in the oil sump and thereby contributes to oil degradation. It leads to shorter oil life and deteriorating lubrication ability. As well as fuel vapor, the blowby gas also includes water steam, which can condensate at low temperatures and subsequently freeze. This is a hazard, particularly with respect to oil pump functionality and venting through the crank case ventilation duct. The main source of the water steam is exhaust gas, which contains water as a product of combustion depending on fuel chemistry. CNG fuel produces a higher fraction of water vapor in the exhaust gas. Numerous measurements carried out at the Skoda Auto laboratories show that the composition of blowby gas can be significantly influenced by piston ring and groove design. Operational conditions of the engine also play an essential role in blowby gas composition. The most important factors are engine speed, EGR ratio (both internal and external), ignition advance and burning rate.

Generally, the composition of raw blowby gas can be divided into three fractions - fresh air, fuel vapor and exhaust gas. The water steam is included in exhaust gas and to a small extent also in wet air. The typical blowby composition of SI engines with port injection technology is shown in Figure 1. The given ratio of the individual fractions depends mainly on engine operational point and piston design.

\section{MEASUREMENT OF BLOWBY}

\section{GAS COMPOSITION}

The direct measurement of species concentration in blowby gas, including $\mathrm{H}_{2} \mathrm{O}$ content, is possible using a FTIR (Fast Fourier Transform Infra-Red) technique with heated lines to the analyzer. Even if the sampling lines are heated, the condensation of both 


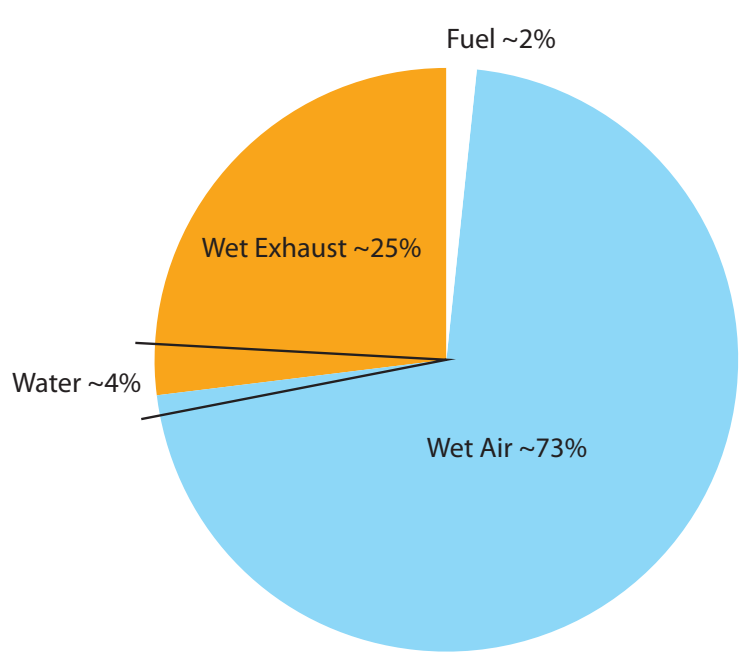

FIGURE 1: Typical raw blowby gas composition of port injection gasoline SI engines.

OBRÁZEK 1: Typické složení neředěných blowby plynů u benzínového zážehového motoru s vnějši tvorbou směsi.

the fuel vapor and the water steam in the cold crank case cannot be completely avoided. Thus the measurement results can be influenced by this issue. If it is not possible to totally prevent the condensation, another method for this task can be applied. The use of more common NDIR analyzers with pre-chiller used routinely for exhaust gas analysis is also applicable. However, in order to obtain proper results it is necessary to apply further recalculation because of water removal from the sample.

The determination of blowby gas composition is mostly based on a comparison between $\mathrm{CO}_{2}$ content in the blowby gas and exhaust gas sampled upstream of the after treatment system [3]. Although the $\mathrm{H}_{2} \mathrm{O}$ content is not measured directly, it can be calculated assuming that the $\mathrm{H}_{2} \mathrm{O} / \mathrm{CO}_{2}$ ratio is constant and corresponds to chemical equilibrium at low temperatures (after chemical reaction freezing at approx. $1700 \mathrm{~K}$ ). This assumption is not far from reality because the blowby gas is formed by combustion products until the flame front reaches the piston rings region. At this time the temperature in the combustion chamber is usually bellow $2250 \mathrm{~K}$ thus the dissociation of combustion products declines in importance. An example of indicated pressure and in cylinder temperatures together with calculated equilibrium $\mathrm{CO}_{2}$ volumetric fraction and $\mathrm{H}_{2} \mathrm{O} / \mathrm{CO}_{2}$ ratio for fuel $\mathrm{C}_{8} \mathrm{H}_{15}$ is given in Figure 2 . The simplified calculation of chemical equilibrium was based on equilibrium constants according to Schüle [1], which provides results in good agreement with [2]. It is clear that rich mixtures are affected by reaction temperatures even at lower temperatures. Calculation analysis shows that the penetration of combustion products through the piston rings area begins at several degrees of crank angle after the end of burning. At this time the incylinder temperature is even lower. Here the assumption of insignificant dissociation allows the use of $\mathrm{CO}_{2}$ as a tracking gas, particularly for stoichiometric and lean mixtures. Rich mixtures can be affected by small errors as can be seen in Figure 2 .

\subsection{CALCULATION OF COMPONENT FRACTIONS BASED ON MEASUREMENT}

Because of the use of conventional NDIR analyzers with a pre-chiller refrigerating the sample to $4-8^{\circ} \mathrm{C}$ it is necessary to take into account condensed water in the gas samples. By means of experimental work, it has been proved that only water condensation takes place in the pre-chiller, there is negligible condensation of gasoline fuel vapors. Assuming only water condensation in the sampling line, the
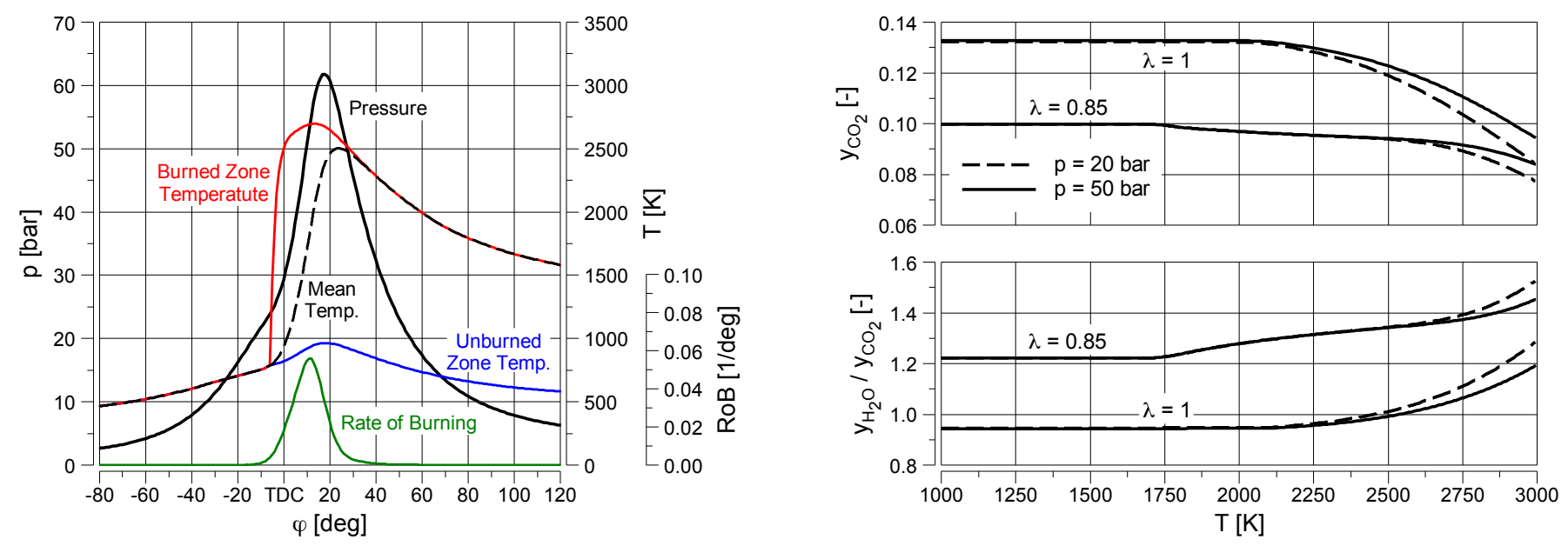

FIGURE 2: Indicated pressure, unburned and burned zone temperatures, rate of burning ( $n=4000 \mathrm{~min}^{-1}, \mathrm{IMEP}=12.2$ bar, $\left.\lambda=0.85\right)$, calculated $\mathrm{CO}_{2}$ equilibrium volumetric fraction and $\mathrm{H}_{2} \mathrm{O} / \mathrm{CO}_{2}$ ratio in exhaust gas as a function of temperature and pressure for fuel $\mathrm{C}_{8} \mathrm{H}_{15}$.

OBRÁZEK 2: Indikovaný tlak, teplota v zóně neshořelé směsi a v zóně spalin, jednotková rychlost hoření ( $n=4000$ min $^{-1}$, IMEP $=12.2$ bar, $\left.\lambda=0.85\right)$, vypočtený rovnovážný objemový podíl $\mathrm{CO}_{2}$ a poměr $\mathrm{H}_{2} \mathrm{O} / \mathrm{CO}_{2}$ ve spalinách v závislosti na teplotě a tlaku pro palivo $\mathrm{C}_{8} \mathrm{H}_{15}$. 
$\mathrm{CO}_{2}$ fractions in blowby and exhaust gas before and after sample drying are related by equations

$\frac{y_{\mathrm{CO}_{2}}^{\mathrm{BB}}}{1-y_{\mathrm{H}_{2} \mathrm{O}}^{B B}}=\frac{y_{\mathrm{CO}_{2}}^{B B^{*}}}{1-y_{\mathrm{H}_{2} \mathrm{O}}^{*}}$

$\frac{y_{\mathrm{CO}_{2}}^{E x h}}{1-y_{\mathrm{H}_{2} \mathrm{O}}^{E x h}}=\frac{y_{\mathrm{CO}_{2}}^{E x h^{*}}}{1-y_{\mathrm{H}_{2} \mathrm{O}}^{*}}$

where variables marked with * denote volumetric fractions after drying. The volumetric fractions of $\mathrm{CO}_{2}$ and $\mathrm{H}_{2} \mathrm{O}$ in the blowby gas are given by the contribution of both wet air and exhaust gas passing through the piston rings region

$y_{\mathrm{CO}_{2}}^{B B}=y_{\mathrm{CO}_{2}}^{A i r} y_{\mathrm{Air}}^{\mathrm{BB}}+y_{\mathrm{CO}_{2}}^{E x h} y_{E x h}^{B B}$

$y_{\mathrm{H}_{2} \mathrm{O}}^{\mathrm{BB}}=y_{\mathrm{H}_{2} \mathrm{O}}^{\mathrm{Air}} y_{\mathrm{Air}}^{\mathrm{BB}}+y_{\mathrm{H}_{2} \mathrm{O}}^{E x h} y_{E x h}^{B B}$

Combining equation systems (1) and (2) results in a formula for the exhaust gas fraction in blowby gas

$y_{E x h}^{B B}=\frac{y_{C O_{2}}^{B B^{*}}-y_{A i r}^{B B}\left[y_{C_{2}}^{A i r}\left(1-y_{\mathrm{H}_{2} \mathrm{O}}^{*}\right)+y_{\mathrm{CO}_{2}}^{B B^{*}} y_{\mathrm{H}_{2} \mathrm{O}}^{\mathrm{Air}}\right]}{y_{\mathrm{CO}_{2}}^{B B^{*}} y_{\mathrm{H}_{2} \mathrm{O}}^{E x h}+y_{\mathrm{CO}_{2}}^{E x h^{*}}\left(1-y_{\mathrm{H}_{2} \mathrm{O}}^{E x h}\right)}$,

where $y_{\mathrm{CO}_{2}}^{E x h *}$ and $y_{\mathrm{CO}_{2}}^{\mathrm{BB}^{*}}$ are directly measured $\mathrm{CO}_{2}$ volumetric fractions in exhaust and blowby gas respectively. The relationship between blowby gas components is given by general mass balance

$y_{\text {Air }}^{B B}+y_{E x h}^{B B}+y_{\text {Fuel }}^{B B}=1$

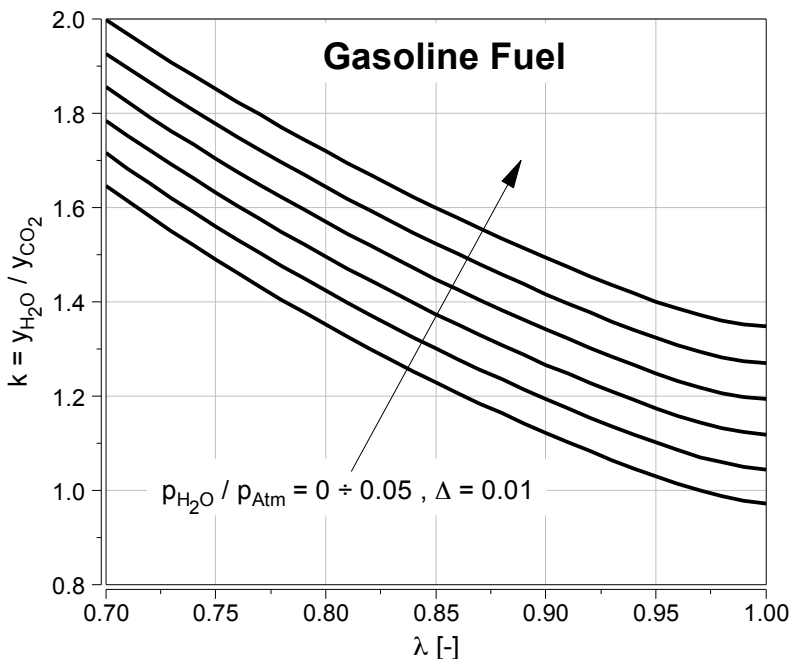

The water steam fraction in exhaust gas can be expressed as

$y_{\mathrm{H}_{2} \mathrm{O}}^{E x h}=\frac{k y_{\mathrm{CO}_{2}}^{E x h^{*}}}{1+k y_{\mathrm{CO}_{2}}^{E x h^{*}}-y_{\mathrm{H}_{2} \mathrm{O}}^{*}}$,

where ratio $k=y_{\mathrm{H}_{2} \mathrm{O}}^{E x h} / y_{\mathrm{CO}_{2}}^{E x h}$ depends on used fuel, air/fuel ratio I and also air humidity. For the purposes of this paper there are shown particular values of the ratio $k$ for gasoline and CNG fuel in Figure 3. These values are calculated considering chemical kinetics at the temperature of reaction freezing according to [4].

Steady-state measurements carried out on port injection engines confirm that the air/fuel ratio in the raw blowby gas roughly corresponds to the air/fuel ratio in the exhaust gas. This means that a nearly homogeneous mixture escapes the combustion chamber by leakage through the piston rings area. Figure 4 shows sequences of different engine operational points for gasoline and CNG fuel comparing measured and calculated fuel volumetric fractions assuming measured values $y_{\text {Air }}^{B B}$ but a homogenous mixture. Measured and theoretically calculated fuel fractions in raw blowby gas display good mutual agreement.

\subsection{SIMPLIFIED CALCULATION}

Considerable simplification of the above-stated calculation procedure is possible by taking into account the following assumptions:

- The inlet air contains neither $\mathrm{CO}_{2}$ nor $\mathrm{H}_{2} \mathrm{O}$,

- Drying out of the sample is perfect without any residual water steam,

- There are no fuel vapors in blowby gas.

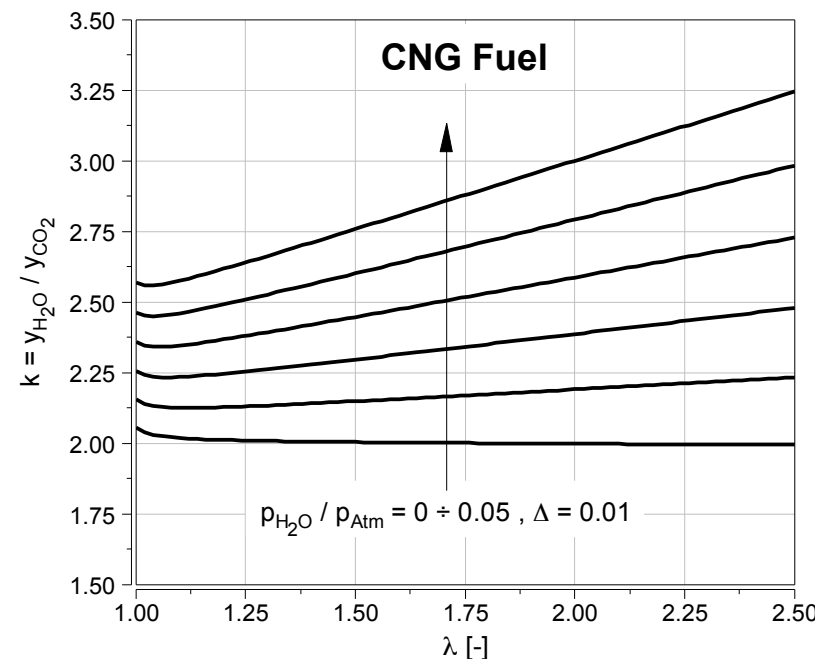

FIGURE 3: Calculated $\mathrm{H}_{2} \mathrm{O} / \mathrm{CO}_{2}$ ratio in exhaust gas as a function of air/fuel ratio $\lambda$ and partial water pressure in air for equivalent gasoline fuel $\mathrm{C}_{7.76} \mathrm{H}_{14.67} \mathrm{O}_{0.12}$ (rich mixtures) and $\mathrm{CNG}$ fuel $\mathrm{CH}_{4}$ (lean mixtures).

OBRÁZEK 3: Vypočtený poměr objemových podílü $\mathrm{H}_{2} \mathrm{O} / \mathrm{CO}_{2}$ ve spalinách v závislosti na součiniteli přebytku vzduchu $\lambda$ a na parciálním tlaku vodních par ve vzduchu pro ekvivalentní palivo $\mathrm{C}_{7.76} \mathrm{H}_{14.67} \mathrm{O}_{0.12}$ (bohaté směsi) a $\mathrm{CNG}$ palivo $\mathrm{CH}_{4}$ (chudé směsi). 


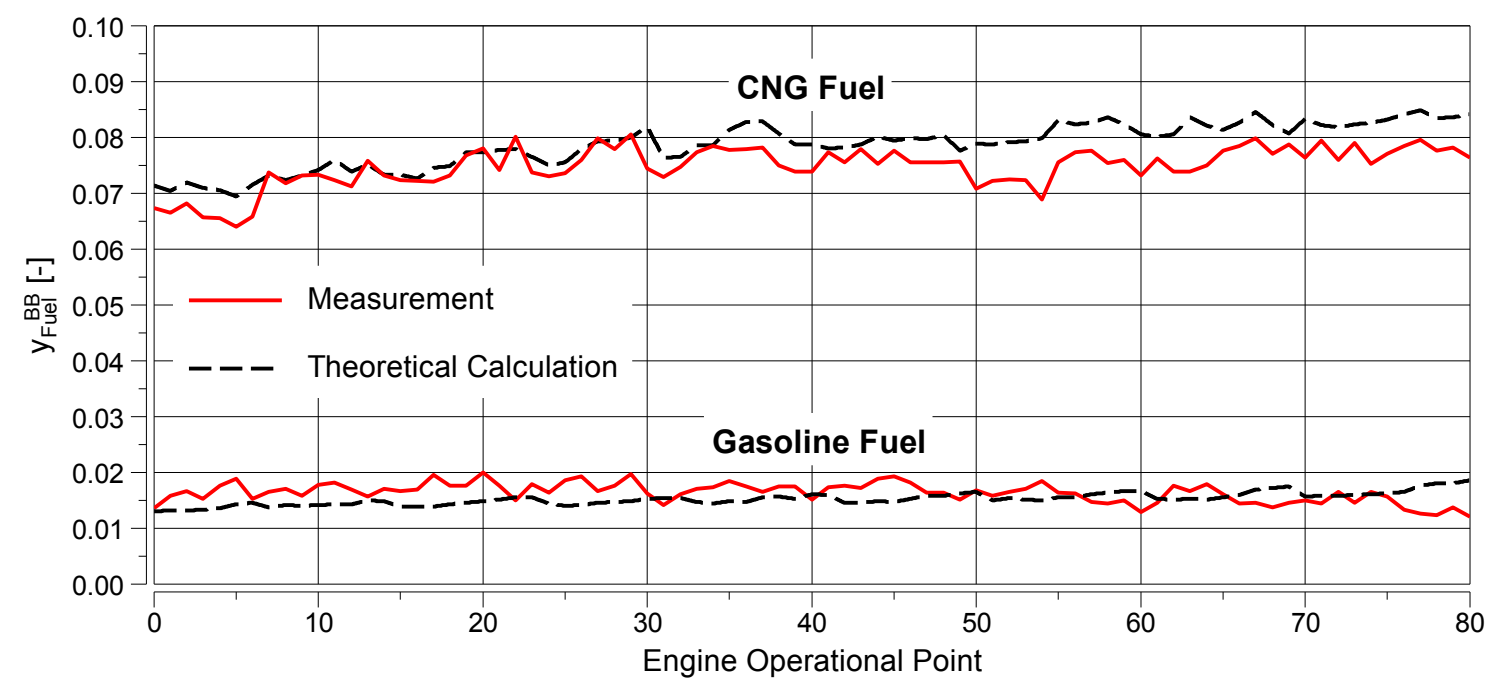

FIGURE 4: Comparison of theoretically calculated and measured fuel volumetric fraction in raw blowby gas at different engine operational points for gasoline and CNG fuel.

OBRÁZEK 4: Porovnání teoreticky spočítaných a změřených objemových podílů palivových par v neředěných blowby plynech při různých provozních režimech benzínového motoru a CNG motoru.

In fact, the last assumption is only temporary. Applying equation (5) and the above-stated assumptions to equation (3) provides the final simplified form for calculation of the exhaust volumetric fraction in blowby gas

$y_{E x h}^{B B} \doteq \frac{y_{C O_{2}}^{B B^{*}}\left(1+K y_{C O_{2}}^{E x h^{*}}\right)}{y_{C O_{2}}^{E x h^{*}}\left(1+K y_{C O_{2}}^{B B^{*}}\right)}$,

where the original ratio $\mathrm{k}$ has been formally replaced by the constant $K$. The new constant $K$ compensates not only for the influence of variable $\mathrm{H}_{2} \mathrm{O} / \mathrm{CO}_{2}$ ratios, but also for the presence of fuel in the blowby gas. The particular value of constant $\mathrm{K}$ depends on the fuel used according to Table 1. These values were obtained by regression analysis of measured data on real engines. Equation (6) was verified with a wide range of exhaust fractions in the blowby gas. The results were compared with a non-simplified calculation as a reference. The error resulting from use of the simplified calculation was $\pm 2 \%$.

Regarding the crank case ventilation design it is desirable to estimate the amount of water vapor in blowby gas. It makes sense to evaluate the occurrence when there is a thread of water freezing inside the crank case. In this case the ambient temperature is below $0^{\circ} \mathrm{C}$ and absolute air humidity is very low. Assuming dry air, the water volumetric fraction in the blowby gas is given as

$y_{\mathrm{H}_{2} \mathrm{O}}^{B B}($ Dry Air $)=\frac{k_{\text {DryAir }} y_{E x h}^{B B} y_{\mathrm{CO}_{2}}^{E x h^{*}}}{1+k_{\text {DryAir }} y_{\mathrm{CO}_{2}}^{E x h h^{*}}-y_{\mathrm{H}_{2} \mathrm{O}}^{*}}$,
TABLE 1: Compensation constants and $\mathrm{H}_{2} \mathrm{O} / \mathrm{CO}_{2}$ ratios for different fuels. TABULLKA 1: Kompenzační konstanty a objemové podíly $\mathrm{H}_{2} \mathrm{O} / \mathrm{CO}_{2}$ pro různá paliva.

\begin{tabular}{lcc}
\hline Fuel & Constant $K$ & Ratio $k_{\text {DryAir }}$ \\
\hline Gasoline & 0.8 & $5.630-8.078 I+3.40912$ \\
\hline CNG & 1.7 & $2.037-0.019 \mid$
\end{tabular}

where the water fraction in the sample after drying $y_{\mathrm{H}_{2} \mathrm{O}}^{\star}$ ranges from 0.006 to 0.01 depending on conditions in the pre-chiller. Ratio $k_{\text {DryAir }}$ for dry air $\left(p_{\mathrm{H}_{2} \mathrm{O}} / p_{A t m}=0\right)$ can be determined from the charts in Figure 3 or can be calculated according to the formulas in Table 1.

\section{MEASUREMENT RESULTS}

All results presented in this paper are related to the raw blowby gas even if an engine was equipped with a PCV (Positive Crank case Ventilation) system. In this case the PCV system was deactivated for measurement purposes. The blowby gas was sampled from the crank case ventilation path downstream of the oil separator. Then the sample was led through the fine filter element to avoid analyzer fouling. All the measurements were carried out under steady-state engine conditions.

Numerous results show that the raw blowby gas composition depends mainly on engine speed and it almost independent of engine load. The charts in Figure 5 show possible values of exhaust gas fraction and of water steam content in blowby gas at normal test cell environmental conditions. These measurements have been carried out on both port injection and direct injection $\mathrm{SI}$ engines. The depicted fields are relatively large, but the area of 

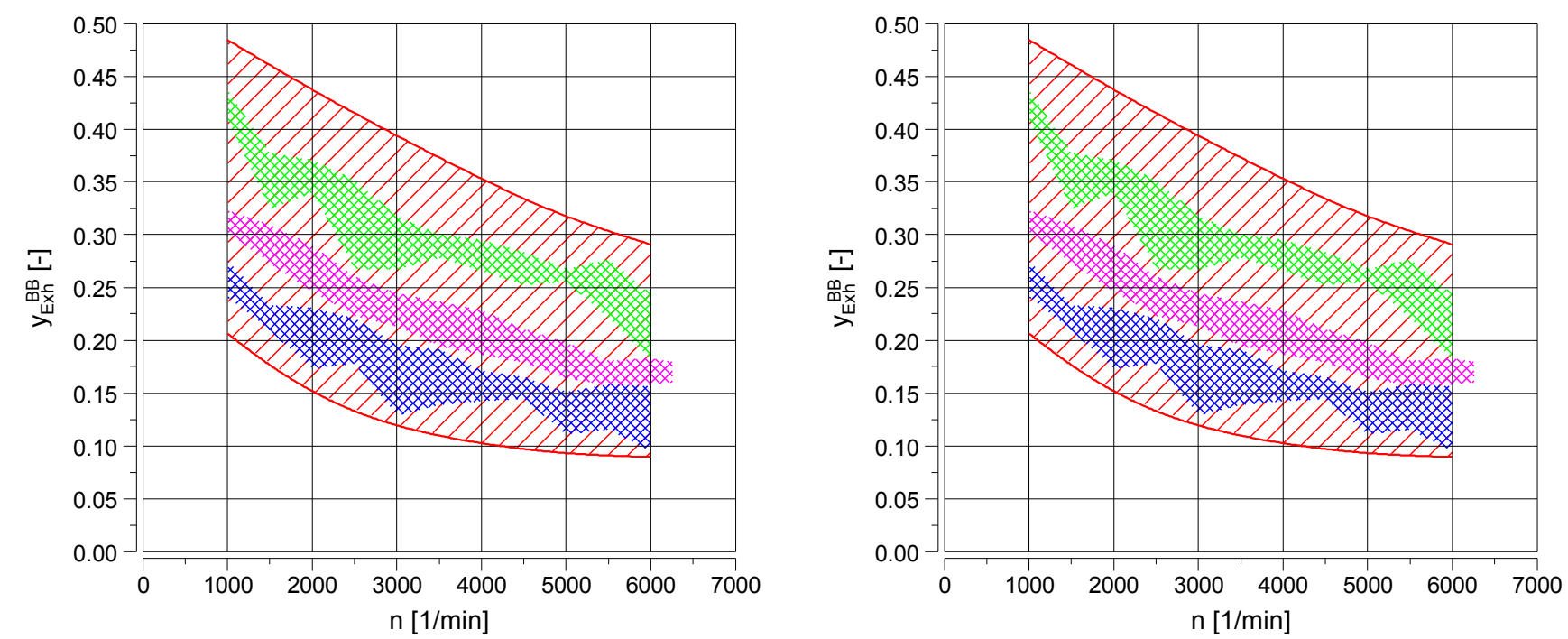

FIGURE 5: Exhaust gas and water steam fraction in raw blowby gas at normal test cell conditions $\left(25^{\circ} \mathrm{C}\right.$, wet air) as a function of engine speed for different gasoline SI engines, highlighted characteristics of single engines.

OBRÁzEK 5: Objemové podíly spalin a vodní páry v neředěných blowby plynech při běžných okolních podmínkách $\left(25^{\circ} \mathrm{C}\right.$, vlhký vzduch) v závislosti na otáčkách motoru pro různé benzínové zážehové motory, zvýrazněná úzká pole přísluší vždy jednomu konkrétnímu motoru.
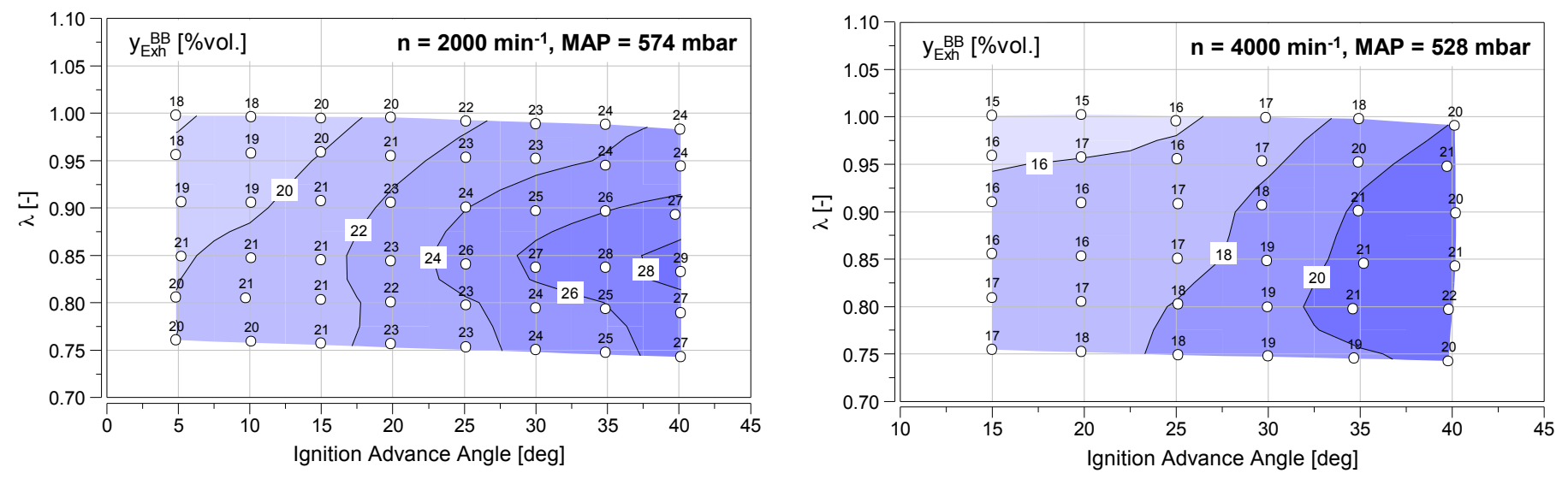

FIGURE 6: Exhaust gas volumetric fraction in raw blowby gas as a function of ignition advance and relative air/fuel ratio $\lambda$, gasoline SI engine, partial loads.

OBRÁZEK 6: Objemové podíly spalin v neředěných blowby plynech v závislosti na předstihu zážehu a součiniteli přebytku vzduchu $\lambda$, režimy středního zatížení benzínového motoru.

possible values for a single engine is relatively narrow. Examples of such measurements for three specific engines at various engine speeds and loads are given. These three highlighted areas cover any possible fraction at any engine operation point. Along with engine speed, the exhaust gas fraction also depends on piston design and soot build up level within piston rings region. Raw engines lie normally in lower range of the field and worn engines lie in upper range.

Besides the engine speed and of course EGR rate there are two more parameters influencing the blowby gas composition, namely air/fuel ratio and ignition advance angle. The specific influence of these two parameters has been investigated at partial engine load at two selected operational points. The results of measurements are graphically displayed in Figure 6.

The exhaust fraction in the blowby gas is strongly affected by ignition timing because it shifts the angular position of the end of combustion. The moment when the flame front reaches a distant piston edge is the most important factor. Until then, only the surrounding unburned mixture can pass through the piston rings area. It is apparent that the air/fuel ratio also has a minor impact on the resulting exhaust gas fraction in blowby gas, partly as the mixture enrichment causes a slight increase in the amount of residual gases passing through the piston rings region together with the unburned mixture. It is generally known that the fastest 

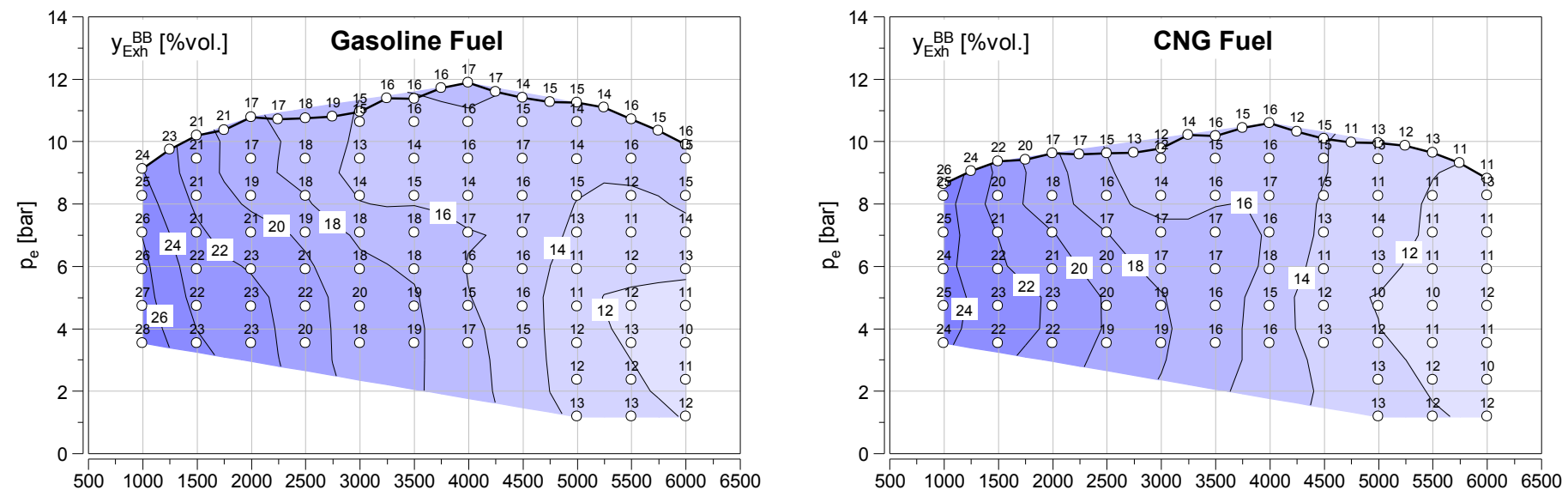

FIGURE 7: Engine map of exhaust volumetric fraction in raw blowby gas for gasoline and CNG fuel.

OBRÁZEK 7: Objemové podíly spalin v neředěných blowby plynech v úplné charakteristice motoru při provozu na benzín a CNG.
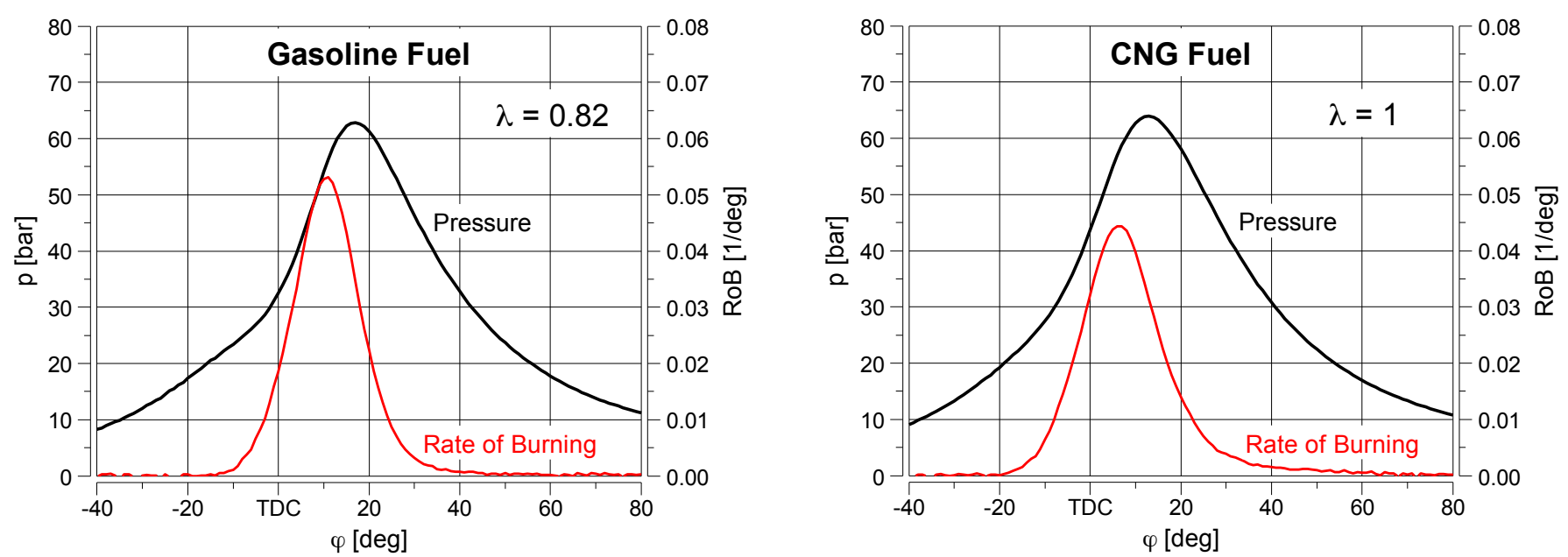

FIGURE 8: Indicated cylinder pressure and normalized rate of burning at engine speed $n=6000 \mathrm{~min}^{-1}$ and full load for gasoline and CNG fuel. OBRÁZEK 8: Indikovaný tlak ve válci motoru a jednotkový průběh hoření při otáčkách $n=6000 \mathrm{~min}^{-1}$ a plném zatížení motoru při provozu na benzín a CNG.

combustion can be expected approximately at an air/fuel ratio $\lambda=0.85$, which corresponds to the peaks in both charts.

For investigation of the fuel influence on blowby gas composition, a fuel bivalent engine was chosen; specifically an SI engine of swept volume 1.6L with port fuel injection system designed to run on gasoline or CNG fuel. The effect of used fuel on exhaust volumetric fraction in blowby gas is presented in Figure 7. Some differences in exhaust fractions are notable only at full load and high engine speeds. The higher ratio of the exhaust in blowby gas in the case of gasoline fuel is caused by faster combustion of a gasoline rich mixture compared to a stoichiometric CNG mixture as indicated in Figure 8.

\section{CONCLUSION}

Blowby gas flow within piston rings region is very complex. However, a simplified explanation of the phenomena mentioned above can be summarized as follows: The piston rings region can be thought as a reservoir. The exhaust gas from the combustion chamber cannot pass through this area until all the mixture in this space is blown-by. There is more time for this phenomenon at lower engine speeds. The higher the soot level, the smaller space between piston rings and consequently more exhaust gas flows through. The exhaust gas fraction in blowby is strongly affected by the burning process in terms of angular position of the end of combustion, which can be simply controlled by 
ignition advance. Residual gases in the combustion chamber contribute markedly to exhaust fraction in blowby gas. A nearly homogeneous mixture escapes the combustion chamber by leakage through the piston rings area in port injection engines. The portion of the fuel vapor in the blowby gas strongly depends on fuel type.

Knowledge of the water steam concentration in the crank case is very important during engine development phase when the crank case ventilation system is being tested and optimized. Investigation of more engines shows their strong diversity. Therefore, the direct measurement of blowby composition for a particular engine is desirable.

The measurement results of raw blowby gas composition can be utilized for a qualitative validation of the piston rings movement simulation.

\section{ACKNOWLEDGEMENT}

This work was supported by ŠKODA AUTO a.s.

\section{LIST OF NOTATIONS AND ABBREVIATIONS}

$\begin{array}{ll}\text { Air } & \text { Wet air } \\ \mathrm{BB} & \text { Blow-by gas } \\ \mathrm{CNG} & \text { Compressed natural gas } \\ \text { DryAir } & \text { Dry air } \\ \text { Exh } & \text { Exhaust gas } \\ \text { Fuel } & \text { Fuel vapour } \\ \mathrm{H}_{2} \mathrm{O} & \text { Water steam } \\ \text { IMEP } & \text { Indicated mean effective pressure } \\ \mathrm{MAP} & \text { Manifold air pressure } \\ \mathrm{NDIR} & \text { Non-dispersive infra-red } \\ \text { RoB } & \text { Rate of burning } \\ \mathrm{SI} & \text { Spark ignition } \\ & \\ k & \text { Volumetric } \mathrm{H}_{2} \mathrm{O} / \mathrm{CO} 2 \text { ratio [-] } \\ n & \text { Engine speed [1/min] } \\ p & \text { Indicated in-cylinder pressure [bar] } \\ p_{\mathrm{Atm}} & \text { Atmospheric pressure [bar] } \\ p_{e} & \text { Engine brake mean effective pressure [bar] } \\ p_{\mathrm{H}_{2} \mathrm{O}} & \text { Water vapour partial pressure in wet air [bar] } \\ T & \text { Calculated in-cylinder temperature [K] } \\ y_{\mathrm{H}_{2} \mathrm{O}}^{*} & \text { Volumetric fraction of water steam in front-end } \\ & \text { condenser [-] } \\ y_{i}^{x} & \text { Volumetric fraction of species i in matter } \mathrm{x}[-] \\ y_{i}^{x^{*}} & \text { Volumetric fraction of species i in matter } \mathrm{x} \text { after drying [-] } \\ \varphi & \text { Crank angle [deg] } \\ \lambda & \text { Relative dry air/fuel ratio [-] } \\ & \end{array}$

\section{REFERENCES}

[1] BURCAT, A., RUSCIC, A.: Third Millennium Ideal Gas and Condensed Phase Thermochemical Database for Combustion with Updates from Active Thermochemical Tables, Argonne National Laboratory, TAE 960, 2005.

[2] GRILL, M.: Objektorientierte Prozessrechnung von Verbrennungsmotoren, Dissertation, Universität Stuttgart 2006.

[3] PÁV, K.: Measurement of Blow-by Gas Composition, XLV. International Scientific Conference of Czech and Slovak University Departments and Institutions Dealing with the Research of Combustion Engines, str. 97-105, Kostelec nad Černými lesy 2014, ISBN 978-80-7375-801-1.

[4] PÁV, K.: Složení výfukových plynů zážehových motorů, Sborník přednášek mezinárodní konference Motor-Sympo, str. 199-206, Vydalo ČVUT v Praze, ÚVMV s.r.o., Výzkumné centrum Josefa Božka, Brno 2001,

ISBN 80-01-02382-6. 